\title{
Demographic and Socioeconomic Characteristics of Out-Migration from Rural Areas of Satna District in Madhya Pradesh, India
}

\author{
Gurjeet Kaur $^{1}$, Safeer Alam ${ }^{2 *}$ and Naushad Alam ${ }^{3}$ \\ ${ }^{1}$ Department of Physical Sciences, Faculty of Science and Environment, M.G.C.G.V.V., \\ Chitrakoot, Satna, M.P., India \\ ${ }^{2}$ Deputy Director Extension, SKUAST-Kashmir, Srinagar, J\&K, India \\ ${ }^{3}$ SMS (Agriculture Extension), Krishi Vigyan Kendra, Thariaon (Fatehpur), CSA University of \\ Agriculture and Technology, Kanpur, U.P., India \\ *Corresponding author
}

\section{A B S T R A C T}

\begin{tabular}{|l|}
\hline Ke y w o r d s \\
$\begin{array}{l}\text { Chi-square, Migration } \\
\text { differentials, } \\
\text { Remittances, Rural- } \\
\text { out migration }\end{array}$ \\
\hline Article Info \\
\hline $\begin{array}{l}\text { Accepted: } \\
\text { 20 March } 2018 \\
\text { Available Online: } \\
\text { 10 April } 2018\end{array}$ \\
\hline
\end{tabular}

This paper addresses the trends as well as migration differentials according to different demographic and socioeconomic characteristics of migrants from rural areas of district Satna in Madhya Pradesh, India. To date, limited research work is done in Madhya Pradesh on the pattern of rural-out migration. For the present study data has been collected on 2150 households using the personal interview method with the help of pre-designed questionnaire. The findings from analyzing the primary data reveals that 'poverty', 'liking of place' and 'better opportunities' are main push-pull factors behind rural-out migration. Migrants in young age group 15-34 years are more prone to migrate, also age at migration and place of destination are closely related to each other. Migration pattern of educated persons in general has undergone a change and there are reasons to believe that, like some job related policies of state government and expansion of many industries in Satna (urban) and other districts of M.P. has attracted a noticeable portion of educated youth. The study further indicates that, a large portion of migrants sent back remittances, which plays a very important role in socio-economic upliftment of other members of household.

\section{Introduction}

Migration is a complex phenomenon having significant geographic, demographic and socio-economic implications on the place of origin as well as on the place of destination. The study of migration has become one of the most important issues of common concern in developing countries and India, being a developing country is facing a high rate of rural to urban migration due to many factors.
The percentage of urban population in India which was only $17 \%$ of the total population in 1951 is expected to rise around $42.5 \%$ of the total population by 2025. Migration is essentially selective with respect to age, sex, caste, marital status, education, occupation etc and propensity of migration differs significantly among these socio-economic groups (Agasty and Patra, 2013; Lee, 1966; Sekhar, 1993; Yadava, 1988). Lusome and Bhagat (2006) carried out a study on 
migration and found that, internal migration is an important factor in influencing social and economic development, especially in developing countries. Sorensen et al., (2002) reported that, the volume of rural to urban migration has increased due to broadening gap in the level of socio-economic development between rural and urban areas, especially in developing nations of the world. In a recent study of determinants of rural to urban migration Patnaik et al., (2015) argued that pattern of migration is a blend of socioeconomic and political factors. Therefore, due to typical characteristics of migrants it is important to understand their intentions of migrations, nature of movement and factors affecting the decision to migrate, for proper urban planning as well as for rural development.

Satna is one of the India's most backward district and there is a strong push of population toward urban areas due to more employment opportunities and presence of more basic amenities as compared to rural areas. Majority of the district's rural population is dependent on agriculture for their livelihood but due to constant land resources, increasing population and lack of on-farm employment opportunities, people are migrating towards the urban areas because migration is seen as a most reliable source of their livelihood. From the literatures it can be find out that very few studies on characteristics of migrants has been carried out in Madhya Pradesh. Therefore, a study of different characteristics of migrants i.e. migration differentials at micro level in light of socio-economic factors is very significant as it may provide deep insight into the factors influencing rural-out migration and that may help in framing more realistic and improved policies for development of rural areas of the state. In this paper migration differential according to number of variables viz. pushpull factors, place of migration, education and remittances sent back in last two years are studied by using the survey data.

\section{Materials and Methods}

The data for the study has been collected under a survey entitled, "A demographic survey of Satna (Rural)-2011", the reference period for the data collection was Dashera and Diwali 2011. A two stage stratified cluster sampling procedure was adopted to select the villages and covered 2150 households of the Satna district. The data has been collected by using personal interview method. To cover the information on migration, a modified definition of household was adopted.

A household is defined as a dwelling unit where a group of persons usually live together and take food from the common kitchen. It however, includes those who have migrated to earn their livelihood. Persons of this category visit their household after long or short intervals and often send remittances. Such persons are called the migrated members of the household and such households are known as migrant household. Moreover married daughters and their children presented at the time of survey are treated as visitors. Servants taking food from the common kitchen are not included in the survey. Data relating to each male migrant aged 15 years and above has been collected.

\section{Reasons for migration}

Migration primarily occurs due to disparities in regional development and like many other developing countries, India is also suffering from the problem of disproportionate development and uneven distribution of basic amenities between rural and urban areas. The causes of migration are usually explained by using two broad categories, namely push and pull factors. Hossain (2001) in the study of rural-urban migration in the ten villages of 
Comilla district of Bangladesh reported that, poverty, job searching and family influence are main push factors for out migration, while better job opportunity, prior migrants and availability of job are the main pull factors behind migration. Patnaik et al., (2015) observed that rural push factors like lack of infrastructure, less income facilities often force people to move and sometimes even if the appropriate facilities are there, still people are moving mostly younger generations because urban attraction is much more than their rural areas. Keeping in view the area of study following push and pull factor are considered

Push Factors: i) Poverty ii) Job Searching iii) Persuasion by someone of the village iv) Persuasion by some family member v) Maladjustment in the family vi) Student (independent) vii) Other viii) Not available

Pull Factors: i) Better schooling facilities ii) Liking of place iii) Transferred iv) Some relatives or friends there v) Better opportunities vi) Secured some job vii) Dependent viii) other

Table 1 presents the percentage distribution of migrants according to different push-pull factors. Over 30 percent of the migrants reported that they migrated due to poverty while another 20 percent did so to find out a better job opportunity. Further, almost 13 percent migrants were pushed off due to the persuasion by their family member. So we can say that, poverty is the main push factor leading to migration from rural areas of district Satna.

It is important to note here that, there is an increase in number of independent students (6.68\%) as compare to past patterns, indicating awareness among people about the higher education which in turn affects the literacy rate of the state. Further, it can be noted from pull factors that about 26 percent of the respondent reported that 'liking of place' is the main pull factor in their process of migration, this may be due to the information carried back by the prior migrants to their villages about the place of their migration. The availability of better schooling facilities, transferable job and better opportunities have been identified as the key pull factors behind the migration accounting $20.68 \%, 20.14 \%$ and $12 \%$ respectively.

\section{Destination of migrants}

The quantity and quality of resources available at a particular place of destination as well as presence of some friends and relatives at that place play an important role in attracting migrants towards it. According to some preestablished routes places of destination are categorized into following seven groups to have significant number of observation for analysis. The groups are (i) Satna (urban) (ii) Madhya Pradesh (excluding Satna urban) (iii) Maharashtra (iv) Gujarat (v) Delhi (vi) Uttar Pradesh and (vii) Others. Figures in Table 2 indicate that migrants from rural areas of Satna are mostly migrated to Satna (urban) and other urban areas of Madhya Pradesh accounting for $43.90 \%$ and $38.18 \%$ respectively.

Further it can be observed that the proportion of migrants to Maharashtra i.e. $7.49 \%$ is found higher as compared to Gujarat (4.09 percent), Delhi (10.79 percent) \& Uttar Pradesh (1.69 percent) respectively. The higher percentage of migrants to Satna (urban) and Madhya Pradesh (excluding Satna urban) may be due to rising job opportunities in newly established industries as well as due to increasing resources for higher education etc. besides these factors involvement of less migratory distance play an important role as it facilitate the migrants to visit their households after short intervals. 
Int.J.Curr.Microbiol.App.Sci (2018) 7(4): 2478-2485

Table.1 Percentage distribution of migrants according to push and pull factors

\begin{tabular}{|c|c|c|c|c|c|c|c|c|}
\hline Factors & \multicolumn{9}{c|}{ Percentage of Migrants } \\
& I & II & III & IV & V & VI & VII & VIII \\
\hline Push & 30.05 & 20.37 & 13.97 & 12.59 & 11.01 & 6.68 & 3.33 & 2.00 \\
\hline Pull & 20.68 & 26.01 & 20.10 & 10.06 & 12.00 & 8.00 & 3.01 & 0.14 \\
\hline
\end{tabular}

Table.2 Percentage distribution of migrants according to place of destination

\begin{tabular}{|c|}
\hline Place of Destination \\
\hline I \\
\hline II \\
\hline III \\
\hline IV \\
\hline V \\
\hline VI \\
\hline VII \\
\hline Total \\
\hline
\end{tabular}

\begin{tabular}{|c|c|}
\hline No. of Migrants & Percentage \\
\hline 944 & 43.9 \\
\hline 821 & 38.18 \\
\hline 161 & 7.49 \\
\hline 88 & 4.09 \\
\hline 17 & 0.79 \\
\hline 36 & 1.69 \\
\hline 83 & 3.86 \\
\hline 2150 & 100 \\
\hline
\end{tabular}

Table.3 Percentage distribution of migrants according to age group and place of destination

\begin{tabular}{|c|c|c|c|c|c|c|c|c|}
\hline $\begin{array}{c}\text { Age } \\
\text { Group }\end{array}$ & \multicolumn{9}{|c|}{ Place of Migration } \\
\hline $\mathbf{0 - 1 4}$ & 13.82 & 7.18 & 10.55 & 3.47 & 8.33 & 11.76 & 4.81 & $\mathbf{6 . 2 3}$ \\
\hline $\mathbf{1 5 - 1 9}$ & 11.12 & 13.03 & 8.07 & 18.18 & 11.09 & 17.64 & 12.06 & $\mathbf{1 2 . 0 0}$ \\
\hline $\mathbf{2 0 - 2 4}$ & 30.50 & 26.08 & 24.22 & 36.20 & 13.90 & 29.43 & 16.87 & $\mathbf{2 4 . 7 7}$ \\
\hline $\mathbf{2 5 - 2 9}$ & 15.99 & 15.65 & 24.25 & 24.30 & 27.78 & 23.53 & 20.49 & $\mathbf{1 7 . 1 6}$ \\
\hline $\mathbf{3 0 - 3 4}$ & 20.20 & 22.06 & 16.14 & 14.32 & 27.80 & 17.64 & 21.69 & $\mathbf{1 8 . 4 7}$ \\
\hline $\mathbf{3 5 - 3 9}$ & 4.24 & 9.92 & 8.70 & 3.40 & 5.65 & 0.0 & 13.25 & $\mathbf{9 . 0 7}$ \\
\hline $\mathbf{4 0 - 4 4}$ & 4.13 & 4.75 & 8.07 & 1.13 & 5.45 & 0.0 & 8.43 & $\mathbf{4 . 7 0}$ \\
\hline $\mathbf{4 5} \mathbf{\&}$ & 0.0 & 1.33 & 0.0 & 0.0 & 0.0 & 0.0 & 2.40 & $\mathbf{7 . 6}$ \\
\hline above & $\mathbf{9 4 4}$ & $\mathbf{9 2 1}$ & $\mathbf{1 6 1}$ & $\mathbf{8 8}$ & $\mathbf{1 7}$ & $\mathbf{3 6}$ & $\mathbf{8 3}$ & $\mathbf{2 1 5 0}$ \\
\hline Total & $\mathbf{9 4 4}$ & $\mathbf{8 2 1}$ & & & & & & \\
\hline
\end{tabular}


Table.4 Percentage distribution according to educational level of migrants and place of destination

\begin{tabular}{|c|c|c|c|c|c|c|c|c|}
\hline $\begin{array}{c}\text { Educational } \\
\text { Group }\end{array}$ & \multicolumn{9}{|c|}{ Place of Migration } \\
\hline I & I & II & III & IV & V & VI & VII & Total \\
\hline II & 15.01 & 8.28 & 16.89 & 24.09 & 4.94 & 6.78 & 11.98 & $\mathbf{1 2 . 6}$ \\
\hline III & 11.02 & 11.85 & 9.01 & 19.05 & 9.98 & 2.81 & 3.78 & $\mathbf{1 1 . 1 1}$ \\
\hline IV & 13.04 & 6.90 & 20.00 & 13.00 & 10.46 & 7.99 & 13.13 & $\mathbf{1 1 . 1 2}$ \\
\hline V & 23.07 & 27.02 & 33.02 & 20.03 & 30.52 & 26.02 & 36.84 & $\mathbf{2 5 . 9 1}$ \\
\hline VI & 7.00 & 21.25 & 8.3 & 15.03 & 18.45 & 23.38 & 13.37 & $\mathbf{1 3 . 4 0}$ \\
\hline Total & 30.86 & 24.70 & 12.78 & 8.8 & 25.65 & 33.02 & 20.90 & $\mathbf{2 5 . 8 6}$ \\
\hline & $\mathbf{9 4 4}$ & $\mathbf{8 2 1}$ & $\mathbf{1 6 1}$ & $\mathbf{8 8}$ & $\mathbf{1 7}$ & $\mathbf{3 6}$ & $\mathbf{8 3}$ & $\mathbf{2 1 5 0}$ \\
\hline
\end{tabular}

Table.5 Percentage distribution of migrants according to place of destination and remittances sent back in last two years

\begin{tabular}{|c|c|c|c|c|c|c|c|c|}
\hline $\begin{array}{c}\text { Remittances } \\
\begin{array}{c}\text { Sent in last } \\
\text { Two years (in Rs.) }\end{array}\end{array}$ & \multicolumn{10}{|c|}{ I } & II & III & IV & V & VI & VII & Total \\
\hline $\mathbf{1 0 0 0 - 2 0 0 0 0}$ & 6.79 & 5.48 & 0.0 & 0.0 & 0.0 & 1.07 & 0.0 & 5.11 \\
\hline $\mathbf{2 1 0 0 0 - 4 0 0 0 0}$ & 11.00 & 24.01 & 12.01 & 9.5 & 13.88 & 10.93 & 0.09 & 15.53 \\
\hline $\mathbf{4 1 0 0 0 - 6 0 0 0 0}$ & 17.16 & 12.06 & 15.49 & 13.36 & 25.44 & 27.48 & 39.16 & 16.10 \\
\hline $\mathbf{6 1 0 0 0 - 8 0 0 0 0}$ & 24.15 & 17.00 & 0.18 & 3.95 & 6.12 & 12.39 & 12.10 & 17.86 \\
\hline $\mathbf{8 1 0 0 0 - 1 0 0 0 0 0}$ & 8.25 & 3.91 & 1.55 & 2.37 & 7.06 & 4.56 & 10.24 & 5.81 \\
\hline $\mathbf{1 0 1 0 0 0 - 1 2 0 0 0 0}$ & 4.08 & 4.5 & 5.12 & 6.15 & 12.90 & 6.50 & 7.73 & 4.60 \\
\hline $\mathbf{1 2 0 0 0 0}$ \& above & 13.92 & 8.03 & 41.00 & 35.55 & 19.37 & 11.56 & 16.39 & 14.85 \\
\hline Money not sent & 14.65 & 25.01 & 24.65 & 29.12 & 15.24 & 25.51 & 14.29 & 20.14 \\
\hline & & & & & & & & \\
\hline Total & 944 & 821 & 161 & 88 & 17 & 36 & 83 & 2150 \\
\hline
\end{tabular}

\section{Age at migration}

Age is a significant factor influencing outmigration. Zacharia (1968) studied the age distribution of migrants to greater Bombay and reported that $81.05 \%$ migrants belonged to the age group of 15-59 years. In a microlevel study on rural-urban migration in Bangladesh, Hossain (2001) has reported that, migrants are usually younger people and migration remarkably decreases with increase in age, majority of rural out migrants belong to the 20-24 years age group. A study by Prasad et al., (2009) on migration to Greater
Mumbai reveals that 68 percent of the migrants migrated when they were below 25 years of age. Table 3 shows the distribution of migrants according to different age groups. The majority of the migrants (77.4\%) belong to 15 and 34 years age group in general and 20-24 years age group in particular. Obvious reason is that, this is the working population which is very much vulnerable to migration. The 20-24 years age group constitutes $27.77 \%$ of the total migrants followed by those having age between 25 and 29 years and accounts for $17.16 \%$ of migrants. The percentage of migrants decreased remarkably with increase 
in age group, proportion of migrants aged 40 years and above is less than $13 \%$.

\section{Educational status of the migrants}

Education is a significant factor in determining the migrant's selectivity. It is an influential source in bringing socio-economic and cultural changes in a society. Migration is an important media for skill transfer of educated migrants (Vakhitova and Coupe, 2014). A number of studies showed that migrants are usually more educated than nonmigrants with respect to the place of origin and less educated than non-migrants with respect to place of destination (Caldwell, 1969; Singh and Yadava, 1981b; Singh, 1985). The selectivity of migration varies according to education of migrants (Agasty and Patra 2013; Patnaik et al., 2015, Zachariah, 1968 etc), the Rural Brain Drain is the obvious phenomena reported by the above researches. To analyze this differential, educational levels of migrants are classified as (i). Illiterate (ii). Upto Primary (iii). Upto Middle (iv). Upto High School (v). Upto Intermediate (vi). Graduate and Post Graduate. It can be analysed from the Table 4, that migrants with high literacy level comprises of more than $60 \%$ of the total migrants. More than $50 \%$ of migrants who have higher level of education (i.e. belong to group vi) mainly migrated to nearby places or in other words, Satna (urban) and other urban areas of Madhya Pradesh. Out of the total proportion about $12.60 \%$ migrants belong to illiterate group whereas $11.11 \%, 11.12 \%$ and $25.91 \%$ belong to primary, middle and higher secondary educational group. Migrants to longer distant places have moderate level of education, who can be engaged mainly in emerging ventures of trade and commerce which need personals with minor educational efficiencies. For testing the degree of independence between education and place of migration $\chi^{2}$-test of significance has been used here. The value of $\chi^{2}$-statistic came out to be highly significant $\left(\chi^{2} \mathrm{cal}=186.57\right.$, d.f. $\left.=30\right)$, showing dependence between place of migration and educational attainment of migrants.

\section{Remittances sent back in last two years}

Catalytic effect of economic factors in influencing migration is clearly recognized by Ravenstein's first law (1885) which states that the great centers of commerce and industry absorb the migrants. In a study of seasonal laborer migration in western India Moose et al., (2005) revealed that people migrate with a view to maximize their income earnings. Turkhade (2012) has mentioned that the low educated or illiterate migrants who are placed in lower job position seems to be more regular in remitting money. Mehta (1991) reported populations with lower income group are always concerned with the poor economic conditions of their households which compel them to contribute as much as possible towards their family income at home. For having a fine view of amount of money sent back in last two years by the migrants, remittances are divided into 8 categories as shown in Table 5. it is evident from the table that percentage of migrants who do not sent back remittances is about $20.14 \%$, this may be due to many factors such as higher cost of living and low income at the place of migration, also migrants who migrate along with their family are less likely to sent back money to their houses. Figures in the table shows that there is a higher percentage of remittances in group II, III and IV (ranges from Rs.21000- Rs.80000) sent back to villages by migrants. Persons migrated to distant places like Maharashtra, Gujarat and Delhi are more prone to send back higher remittances to their families as compared to those who migrated to other places. Further analysis of table values (excluding the column of money not sent back) shows that 
remittances sent back are associated with place of migration. The value of $\chi^{2}$ test statistic is found to be significant $\left(\chi^{2}\right.$ cal $=370.15$, d.f. $=42$ ), showing association between place of migration and money sent back in last two years.

It may be concluded from the present study that 'Poverty' is the main push factor for illiterates and moderately educated persons, while 'liking of the place' and 'better schooling facilities' are the main pull factors at migratory places. While addressing the complex issue of migration from Satna (rural), that young adult males in the age group 15-34 years are more prone to migrate.

It has been observed here that educated males have more options for immigration, but they prefer to migrate to nearby places showing great association between educational standards of migrants and choice of their destination. Expansion of industries in Satna (urban) and other districts of M.P. contribute to a large extent in this change, as these industries attract a considerable number of educated persons. This study further conclude that illiterates and low educated persons prefer to migrate to far-flung destinations such as Maharashtra, Gujrat and Delhi indicating towards the reasons that some relatives or prior migrants from their villages already leaving there and higher rate of daily wages at these places. It is observed that very large percentage of migrants sent back remittances to their houses in their native villages, which plays an important role in up liftment of their socio-economic status back in native place. Also there is a great association between place of migration and money remitted back. It may be further concluded that policy makers should focus on the trends and socio-economic effect of migration from rural areas and come out with some policies, so that we have a balanced rural-urban migration.

\section{References}

Agasty, M. P. and Patra, R. N. (2013); Ruralurban Migration: Selectivity, determinants and Destination, Indian Journal of Research, 2(2), pp: 84-86.

Caldwell J.C. (1969); African rural urban migration: the movement to Ghana's town New York, Columbia University Press, London.

Hossain, M.Z. (2001); Rural-Urban Migration in Bangladesh: A Micro-Level Study, for presentation in poster session on internal migration at the Brazil IUSSP conference during August 20-24, 2001.

Lee, E.S. (1966); A Theory of migration, Demography, vol. 3, pp: 47-57.

Lusome, R. and Bhagat, R.B. (2006); Trends and Patterns of Internal Migration in India, 1971-2001, paper presented at the Annual Conference of Indian Association for the Study of Population (IASP) at Thiruvananthapuram during 7-9 June.

Mehta, G.S. (1991); Socio-economic aspects of migration, Deep and Deep Publication, New Delhi.

Mosse, D., Gupta, S. and Shah, V. (2005); on the margins in the city, Adivasi seasonal labour migration in Western India, Economic and Political Weekly.

Patnaik, B.C.M., Satpathy, I., Monanty, J. and Mandal, A. (2015); Determinants of migration from rural to urban India by the labourer- An Overview, Journal of Business Management \& Social Sciences Research, vol. 4(1), pp: 33-38.

Prasad R., Singh, M.N., Das, K.C., Gupta, K., and Bhagat, R.B. (2009); Migration to Greater Mumbai urban agglomerations: Study of characteristics of principle migrants and their social linkages, demography India, vol. 38(2), pp: 319334. 
Ravenstein, E.G. (1885); The laws of migration, Journal of Statistical Society, vol. 48(2), pp: 167-227.

Shekhar, T.V. (1993); Migration selectivity from rural areas, Evidences from Kerala, Demography India, Vol. 22 (21), pp: 191-202.

Singh S.N. and Yadava K.N.S. (1981); On some characteristics of rural out migration in eastern Uttar-Pradesh, Society and Culture, 12(1), pp: 33-46.

Singh, S.R.J. (1985); A study of rural outmigration and its effect in fertility, Unpublished Ph.D. thesis in Statistics, B.H.U., India.

Sorensen, N.N., Hear, N.V. and Pederson, P.E. (2002); The MigrationDevelopment Nexus Evidence and
Policy Options, International Organization for Migration, pp: 7.

Turkhade, Gaurav (2012); Migration: Impact $\&$ relevance of remittance on rural Areas. Kurukshetra, 60(4), pp: 16-19.

Vakhitova, H. and Coupe, T. (2014); The relationship between education and migration, Weekly Policy Brief Series, pp: $1-5$.

Yadava K.N.S. (1987); Volume and pattern of Rural-Urban migration in India, Seminar paper presented in the department of demography, Australian National University, Canberra.

Zacheriah K.C. (1968); Migration in greater Bombay. Asia publishing house, Bombay.

\section{How to cite this article:}

Gurjeet Kaur, Safeer Alam and Naushad Alam. 2018. Demographic and Socioeconomic Characteristics of Out-Migration from Rural Areas of Satna District in Madhya Pradesh, India. Int.J.Curr.Microbiol.App.Sci. 7(04): 2478-2485. doi: https://doi.org/10.20546/ijcmas.2018.704.284 